\title{
Complex ophthalmoplaegia denoting Wernicke encephalopathy in a non-alcoholic individual
}

\section{Ana Aires, ${ }^{1}$ João Pedro Filipe, ${ }^{2}$ Maria Carolina Garrett, ${ }^{1}$ Raquel Real ${ }^{1}$}

'Department of Neurology, Hospital São João, Porto, Portugal

${ }^{2}$ Department of

Neuroradiology, Hospital São João, Porto, Portugal

\section{Correspondence to}

Professor Maria Carolina

Garrett,

garrett.mc51@gmail.com

Accepted 7 March 2015

\section{DESCRIPTION}

A 62-year-old man presented with subacute horizontal binocular diplopia and slight gait imbalance, preceded by frequent episodes of vomiting. The patient had undergone two gastric surgeries for gastric ulcer in the past (in 1988 and 2002). Bilateral internuclear ophthalmoplaegia, conjugate vertical gaze palsy and mild tandem gait abnormalities were observed (video 1, part 1; figure 1). Upper gastrointestinal endoscopy and gastric emptying scintigraphy
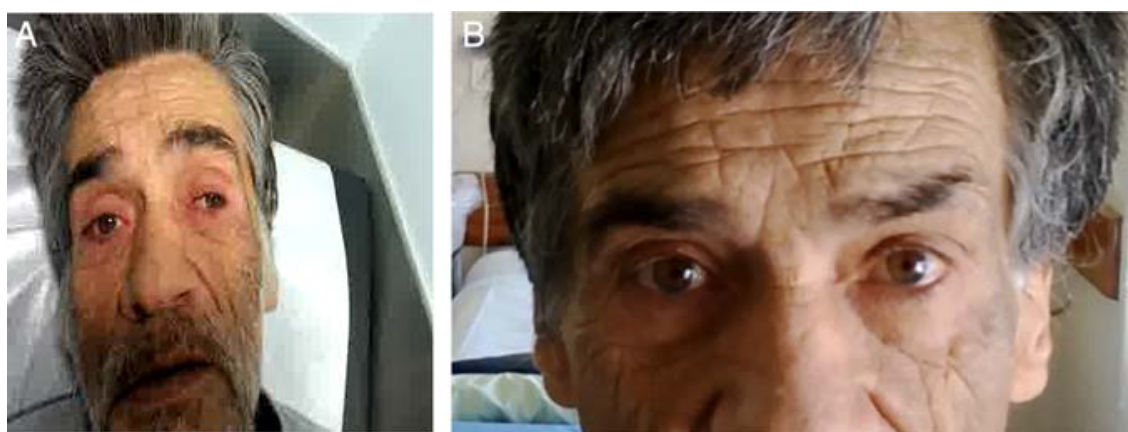

Video 1 Part 1 demonstrates bilateral internuclear ophthalmoplaegia and conjugate vertical gaze palsy. Part 2 was obtained after administration of intravenous thiamine and shows a full recovery of conjugate eye movements.
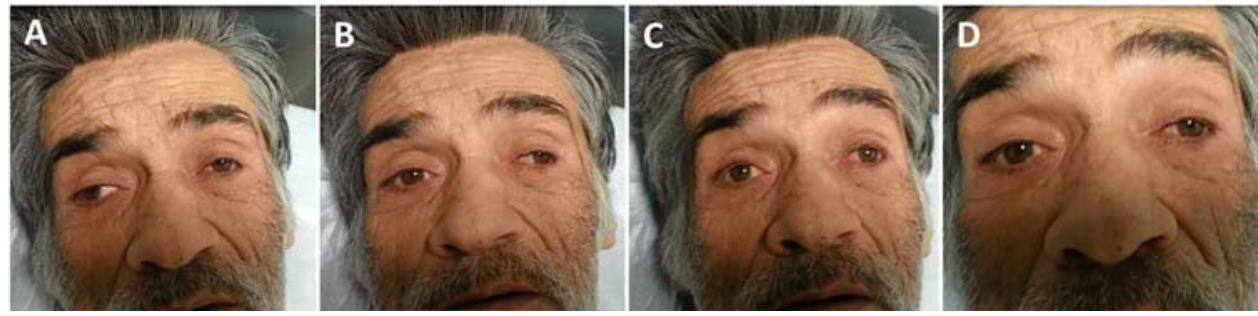

Figure 1 On admission, position of the patient's eyes when asked to look (A) right, (B) left, (C) up and (D) down.
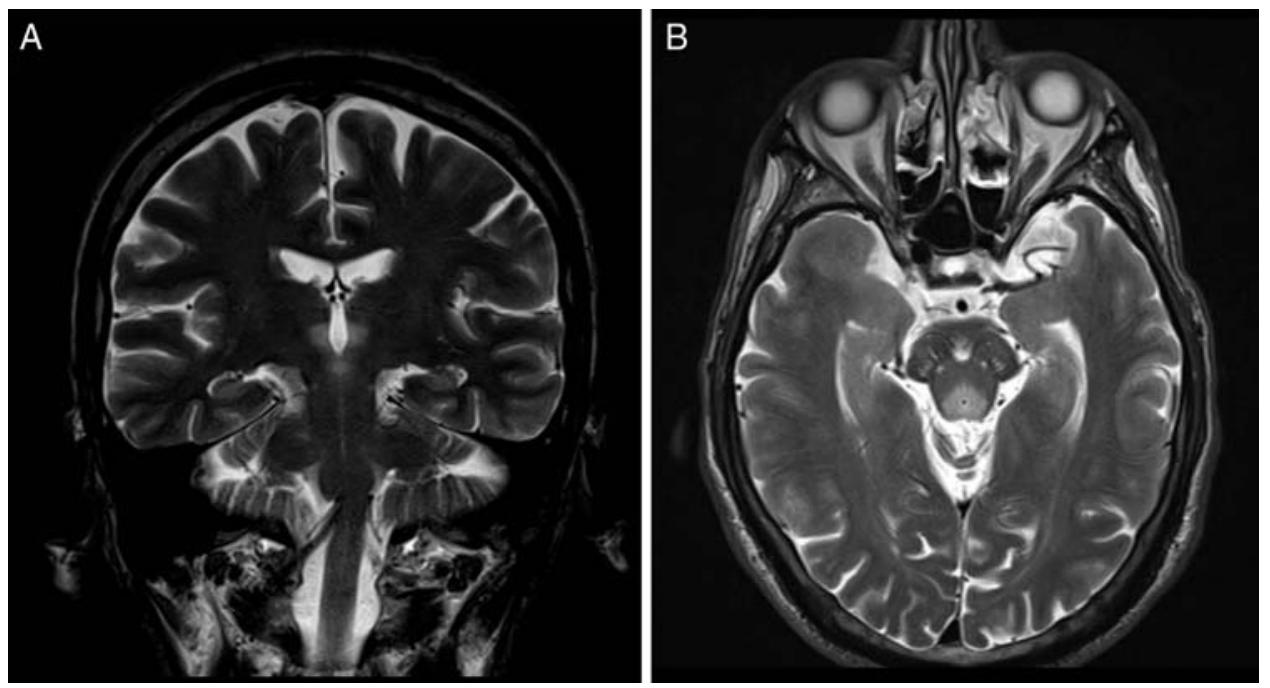

To cite: Aires A, Filipe JP, Garrett MC, et al. BMJ Case Rep Published online:

[please include Day Month Year] doi:10.1136/bcr-2014207284

Figure 2 Coronal T2-weighted turbo spin-echo (T2TSE) (A) and axial T2TSE (B) MRI of the brain reveal T2 hyperintense lesions extending symmetrically from the floor of the fourth ventricle cranially along mesencephalic tegmentum and quadrigeminal plate up to the medial thalami, without significant expansion, presenting slight gadolinium enhancement. 


\section{Learning points}

- This case demonstrates the clinical heterogeneity of Wernicke encephalopathy, with the classical triad (encephalopathy, ataxia and oculomotor abnormalitieshorizontal nystagmus being the most frequent) present in only up to a third of cases. ${ }^{3}$

- Albeit more frequent in alcoholic individuals, it can also occur in patients having a deficit in thiamine absorption for whatever reason, including emesis.

- Brain MRI is the single most important diagnostic tool and it usually depicts hyperintense signal on T2-weighted sequences, with variable enhancement, typically in periventricular and periaqueductal midline locations. Other typical findings include symmetric involvement of the medial thalami, mammillary bodies and tectal plate. Atypical findings are thought to be more frequent in non-alcoholic cases. Also, signal intensity alterations, contrast enhancement and atrophy of the mammillary bodies, as well as atrophy of the cerebellar vermis, are more common in alcoholic than non-alcoholic patients. ${ }^{3}$ Keeping these differences in mind is fundamental for an accurate diagnosis of the more uncommon non-alcoholic Wernicke encephalopathy.

suggested a delay in gastric emptying. Brain MRI demonstrated hyperintense symmetric areas in the thalami, midbrain tegmentum, quadrigeminal plate and floor of the fourth ventricle, suggesting Wernicke encephalopathy (figure 2). Intravenous thiamine (200 $\mathrm{mg}$ three times a day, as recommended) was administrated for 15 days, followed by oral thiamine. ${ }^{1}$ Serum thiamine concentration was impossible to determine (since this measurement is not performed in our centre), but sustained resolution of the patient's neurological signs and symptoms within 4 days, in the absence of additional therapeutic measures besides thiamine supplementation, confirmed the diagnosis of Wernicke encephalopathy (video 1 , part 2$)^{2}$

Contributors AA, RR and JPF contributed to data acquisition and analysis. All authors contributed to the conception and design of the manuscript, were involved in drafting/revising the manuscript and approved its final version.

Competing interests None.

Patient consent Obtained.

Provenance and peer review Not commissioned; externally peer reviewed.

\section{REFERENCES}

1 Galvin R, Bråthen G, Ivashynka A, et al. EFNS guidelines for diagnosis, therapy and prevention of Wernicke encephalopathy. Eur J Neurol 2010;17:1408-18.

2 Sechi G, Serra A. Wernicke's encephalopathy: new clinical settings and recent advances in diagnosis and management. Lancet Neurol 2007:6:442-55.

3 Zuccoli G, Pipitone N. Neuroimaging findings in acute Wernicke's encephalopathy: review of the literature. AJR Am J Roentgenol 2009; 192:501-8.

Copyright 2015 BMJ Publishing Group. All rights reserved. For permission to reuse any of this content visit http://group.bmj.com/group/rights-licensing/permissions.

BMJ Case Report Fellows may re-use this article for personal use and teaching without any further permission.

Become a Fellow of BMJ Case Reports today and you can:

- Submit as many cases as you like

- Enjoy fast sympathetic peer review and rapid publication of accepted articles

- Access all the published articles

- Re-use any of the published material for personal use and teaching without further permission

For information on Institutional Fellowships contact consortiasales@bmjgroup.com

Visit casereports.bmj.com for more articles like this and to become a Fellow 